症例報告 一専門医最優秀ポスター賞受賞一

\title{
広沉型侵襲性歯周炎患者に歯周再生療法を含む 包括的歯周治療を行った一症例
}

\author{
久保田浩三＼cjkstart横田＼cjkstart誠 \\ 九州歯科大学口腔機能科学専攻口腔治療学講座歯周病制御再建学分野
}

\begin{abstract}
A Case Report of Comprehensive Treatment by the Periodontal Regeneration Technique for Aggressive Periodontitis.
\end{abstract}

\section{Kohzoh Kubota and Makoto Yokota}

Department of Cariology and Periodontology, Devision of Periodontology, Kyushu Dental College.

\begin{abstract}
Generalized aggressive periodontitis is a rarely encountered condition characterized by rapid periodontal destruction in otherwise healthy subjects In this paper, inclusive comprehensive treatment including periodontal surgery, induction of periodontal regeneration, tooth transplantation and orthodontic treatment in a patient diagnosed to have generalized aggressive periodontitis is reported. A 21-year-old female with the chief complaint of mobility of the lower anterior teeth and swelling of the gingiva was diagnosed as having severe attachment loss and bone resorption by the clinical and radiographic examinations.

The family medical history of the patient revealed that the paternal uncle had started using complete dentures in his prime and that a cousin of similar age also had similar symptoms.

After the initial therapy, periodontal surgery was performed for the molars, with the maxillary right first molar extracted and the third molar of the same side transplanted at the same time. Enamel matrix derivatives (EMD) was also applied on the maxillary and mandibular left molars. The maxillary teeth were corrected by orthodontic treatment and fixed by prosthetic restoration. The result showed a well-improved periodontal tissue. The 4-year follow revealed successful progress. Nihon Shishubyo Gakkai Kaishi (J Jpn Periodontol) 49 : 151 $161,2007$.
\end{abstract}

Key words : aggressive periodontitis, periodontal regeneration technique, comprehensive treatment

要旨：広汎型侵襲性歯周炎は，歯周炎を除き全身的に健康ではあるが，急速な歯周組織破壊，家族内発現を認 めることを特徵とする歯周炎である。本報では, 広汎型侵襲性歯周炎と診断された患者に対して, 歯周外科, 歯 周再生療法, 歯移植掞よび歯科矯正治療を含めた包括的な治療を行った。患者は 21 歳の女性で, 下顎前歯部の動 摇, 歯肉の発赤腫脹を主訴に来院した。臨床診査扔よびX 線診査によって, 高度なアタッチメントロスと歯槽骨 の吸収が多くの部位で認められた。家族歴として, 父方叔父が壮年の早い時期から総義歯であったこと, 母方従

\footnotetext{
連絡先 : 久保田浩三

于 803-8580 北九州市小倉北区真鶴 2-6-1

九州歯科大学口腔機能科学専攻口腔治療学講座 歯周病制御再建学分野

Kohzoh Kubota

Department of Cariology and Periodontology, Devision of Periodontology, Kyushu Dental College.

2-6-1, Manazuru, Kokura-kitaku, Kitakyushu 803-8580, Japan

E-mail k-kubota@kyu-dent.ac.jp
} 
兄弟が患者と同年代で同様な症状を示していた。歯周基本治療終了後臼歯部において歯周外科を行った，その際 上顎右側第一大白歯は抜歯し，同側第三大臼歯を移植した，また上下顎左側臼歯部に掞いてはエナメルマトリッ クスデリバティブ $(\mathrm{EMD})$ を応用した。その後上顎に歯科矯正治療を行い最終補綴処置を行った。その結果，歯 周組織の良好な改善が認められた。術後 4 年間のメインテナンスを行っているが経過は良好である。

キーワード：広沉型侵襲性歯周炎 歯周再生療法 包括的歯周治療

\section{緒言}

従来から，歯周疾患は少しづつ用語の使い方を異に して分類されてきた。しかし，基本的には歯周疾患を 炎症性病変と退行性病変の 2 つに大きく分類するもの であった。

Orban, Glickman, Goldman \& Cohen, などの 1980 年以前の著名な成書では，すべてそのように分類され ていた。非炎症性の歯周組織の破壊をきたす退行性病 変として歯周症 (Periodontosis) という概念があり, 若 年者に見られる重篤な歯周炎をここに分類する考え方 であった1)。しかし，1970 年代後半から歯周疾患も歯 周ポケットに生息する細菌の感染によって成立する炎 症であり，口腔細菌による感染症であるという概念が 定着してきた。そのことにより, 歯周病を Host-Parasite relationの概念から考えた分類が, Page and Schroeder (1982) $)^{2)}$ によなされた。彼ら は，歯周炎を前思春期性歯周炎，若年性歯周炎，急速 進行性歯周炎, 成人性歯周炎, 急性壊死性潰瘍性歯肉 炎/歯周炎の 5 つの型に分類した。宿主の免疫機構の 欠陥が，ある種の歯周疾患の発症に関係することを考 慮に入れた分類となっている。これを基に 1989 年ア メリカ歯周病学会は, 歯周炎を成人性歯周炎, 早期発 現型歯周炎, 全身疾患が関与した歯周炎, 壊死性潰瘍 性歯周炎，難治性歯周炎の 5 つに分類した。さらに, 早期発現型歯周炎を前思春期性歯周炎, 若年性歯周炎, 急速進行性歯周炎に分けた。また，前思春期性歯周炎 と若年性歯周炎はさらに限局型と広沉型に分けられ $た^{3)}$ 。

さらに, 1999 年 AAP は Workshop を開き新しい分 類作業を行い, AAP 分類として発表した ${ }^{4)}$ 。大きな 枠組みとして, 歯肉炎, 歯周炎, 炎症以外の問題とさ れた。新しい分類で大きく変更されたのは, 早期発現 型歯周炎である。早期発現型歯周炎という考方方から 年齢に関係なく急速に進行する歯周炎として, 侵襲性 歯周炎と変更された。これは，歯周炎を除き全身的に 健康ではあるが，急速な歯周組織破壊，家族内発現を 認めることを特徵とする歯周炎である。日本歯周病学 会においてもこの分類を採用している5)。治療におい
ては, 疾患のリスクファクターを早期に排除すること, 歯周治療の原則に則り, 歯周基本治療, 歯周外科治療, メインテナンスが重要とされている。細菌検査によっ ては, 抗菌薬の全身投与も推奨されている ${ }^{6)}$ 。歯周外 科治療に抢いては, 歯周組織再生療法の効果, どの再 生療法がより効果的であるのか, 併用療法の有効性は 大きいのか，についての報告はいまだに少ない。

本報では, 広沉型侵襲性歯周炎患者に, 歯周外科, 歯移植掞よび歯科矯正治療を含めた包括的な治療を 行って, 良好な改善が見られた症例について報告する。

\section{症例}

患者は 21 歳の女性で, 1998 年 3 月 6 日下顎前歯部 の動摇, 歯肉の発赤腫脹を主訴に来院した。全身的既 往歴に特記事項はなく, 喫煙歷もない。家族歴として 父方叔父が壮年早期より総義歯を使用していた。ま た，同年代の母方従兄弟が患者と同じような症状を示 していた(図 1$)$ 。現病歴として近医にて 2 年間ほどカ リエス治療を中心に治療を受けていたが, 歯肉の腫脹 を繰り返すなど, 治療効果が思わしくなかった。患者 は, 無口で我慢強い夕イプである。我々は, 患者の心 理学的特性を知るために STAI (State-Trait Anxiety Inventory）による不安尺度を調べている7 が，それに よると特性不安 $42 \mathrm{~N}$ (高い), 状態不安 39 III (普通)で あった。

\section{1. 現 症}

1) 口腔内所見

図 2 に初診時の口腔内写真を示す。全顎的に辺縁歯 肉, 歯間乳頭部に発赤, 腫脹が認められる。全顎的に 多数の出血点を認め前歯部で排膿が見られた。前歯部 では歯列不正がみられ, 多数歯に軽度から重度の動摇 が認められる。

2) X 線所見

初診時の X 線写真(図 3)より, 全顎的に高度な水平 性・垂直性骨吸収がみられた。前歯部および上下顎第 一大臼歯においては深い垂直性骨吸収が認められた。

3) 歯周組織検査

図 4 に初診時の歯周組織検查結果を示す。28 歯中 25 歯に $6 \mathrm{~mm}$ 以上の深いポケットが認められ，全体の 


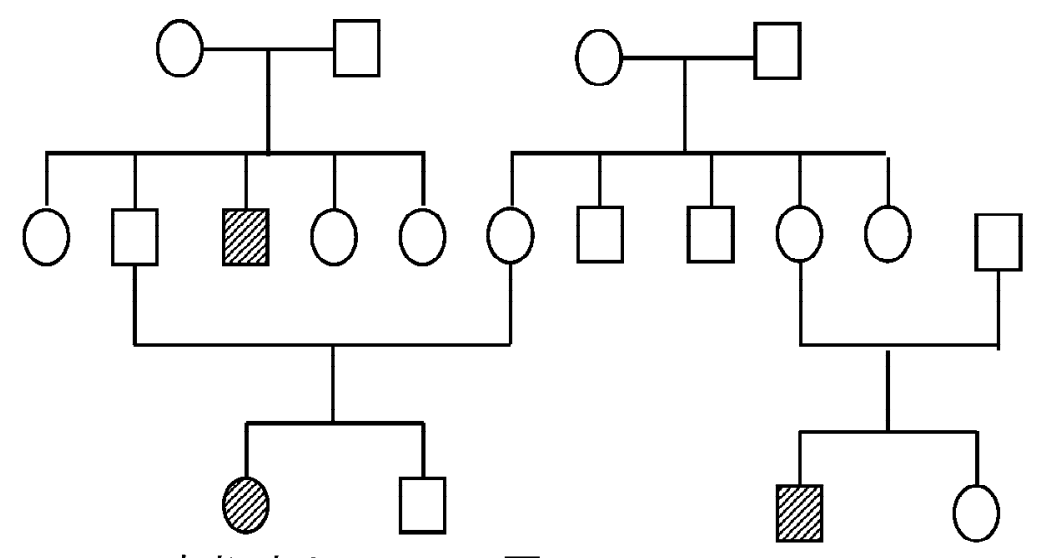

患者:本人

四APの疑い 従兄弟

図 1 症例の家族系統図 (AP : 侵襲型歯周炎)
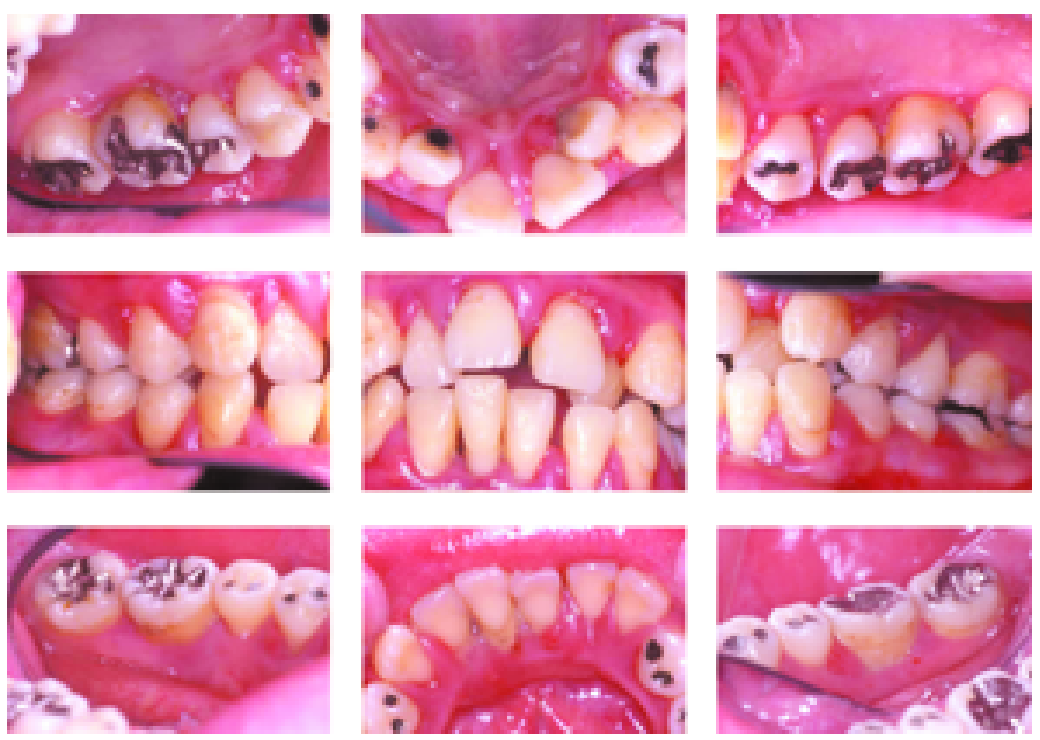

図 2 初診時の口腔内写真

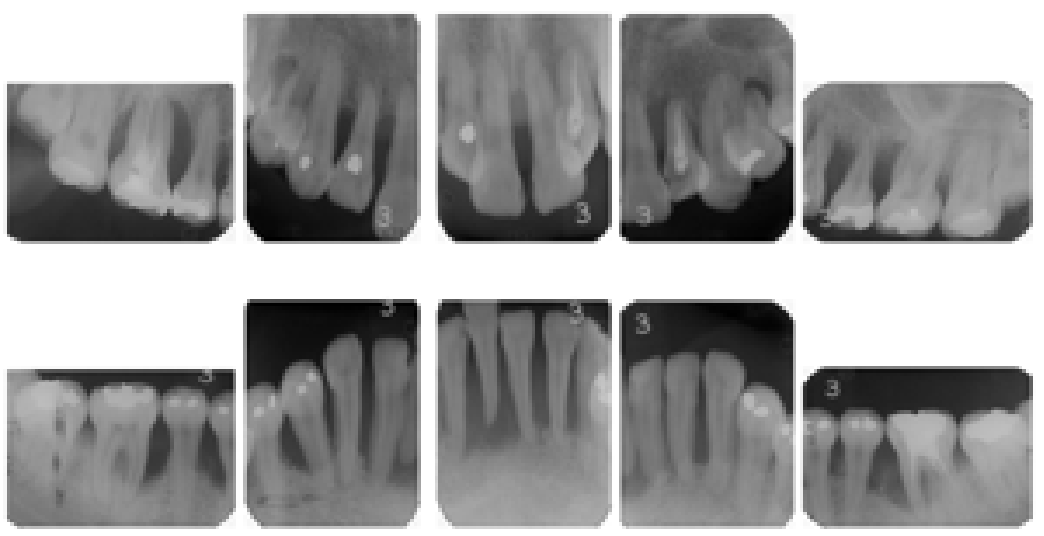

図 3 初診時の X 線写真 


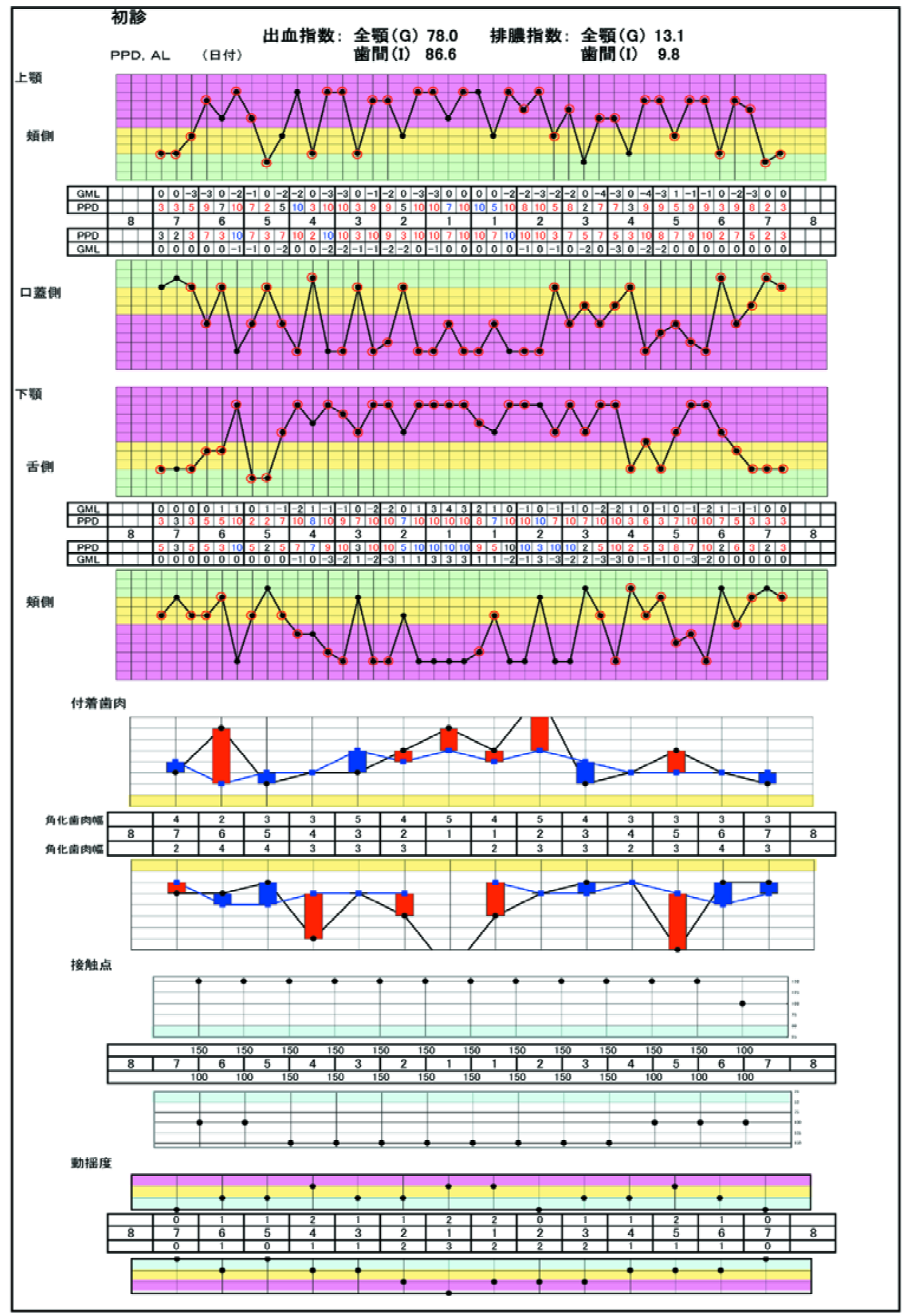

図 4 初診時の歯周組織検査 


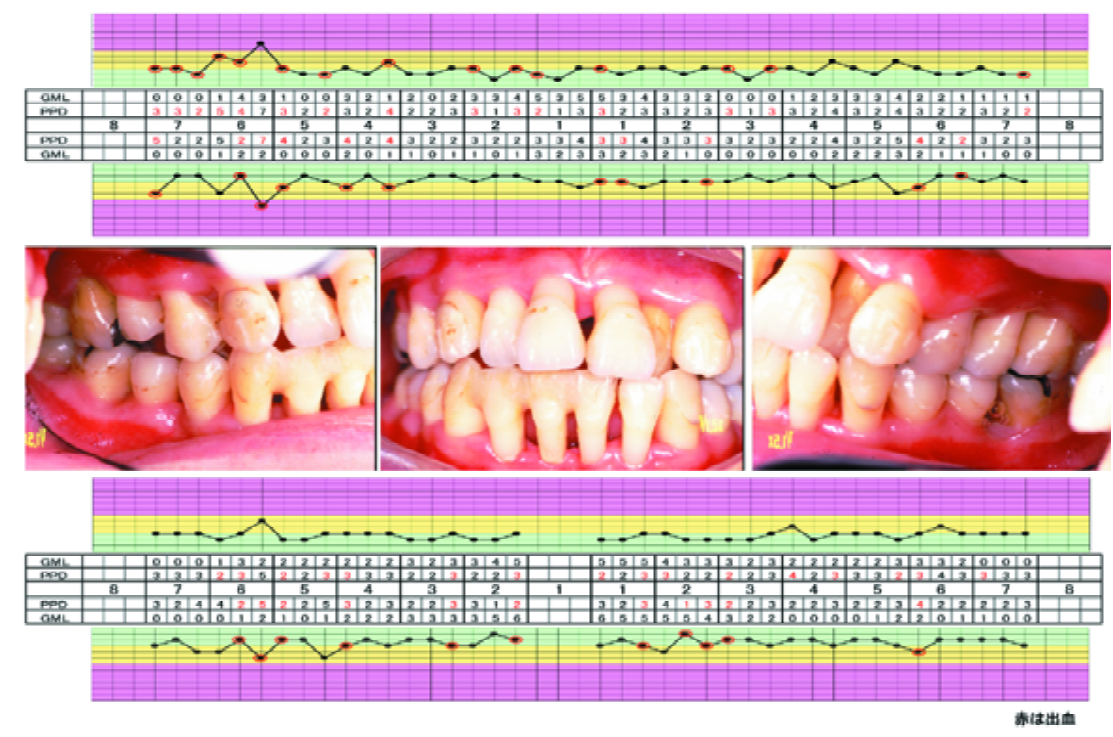

図 5 歯周基本治療後の口腔内写真と歯周組織検査

$54 \%$ におよんでいた $(4 \mathrm{~mm}$ 以上が $72 \%)$ 。平均プロー ビングポケットデプス(PPD)は $6.4 \mathrm{~mm}$ であった。出 血指数は全体で 78\%, 歯間部で $86.6 \%$ であり, 排膿指 数は全体で $13.1 \%$, 歯間部で $9.8 \%$ であった。O' Leary のプラークコントロールレコード (PCR) は $76 \%$ で，動摇度は 21 歯に 1 度から 2 度の動摇がみら れ，下顎右側中切歯は 3 度の動摇がみられた。根分岐 部病変は上顎右側第 1 大臼歯 (Class III)，上顎左側第 1 大臼歯 (Class II), 下顎左側第 1 大臼歯 (Class II), 下顎右側第 1 大臼歯 (Class I ) が認められた。

4) 細菌検査

DNA Probe 検査により上顎右側中切歯近心より Provotella intermedia, Eikenella corrodens が検出さ れた。

\section{1. 診断および治療方針}

以上の検査結果より，歯周炎を除き全身的に健康で はあるが，第 1 大臼歯と前歯以外の部位で，少なくと も3 歯以上で広沉なアタッチメント・ロスがみられ, 急速な歯周組織破壊を示し，家族内発現を認めること により広汎型侵襲性歯周炎と診断した。治療方針とし て，歯周基本治療と歯周組織再生療法を含む歯周外科 治療, 歯移植, 歯科矯正治療, 最終補緅処置を行い咬 合・咀嚼の回復を計画した。

\section{治療経過}

1）歯周基本治療 (1998 年 3 月〜 1998 年 10 月) 口腔衛生指導，スケーリング，ルートプレーニ ング $(\mathrm{SRP}) 43$ 〜 33 の SRP 時に 41 の抜歯および 暫間固定，咬合調整，歯内治療 $(17,16,15 ， 14$, $24,25,26,35,36,46)$

2) 再評価 (1998 年 10 月)

3）歯周外科 (1999 年 2 月〜 2000 年 6 月)

17 ～ 13 フラップ手術 16 抜歯， 18 を 16 に歯移 植， 47 〜 44 フラップ手術 48 抜歯， $\quad 24 \sim 27$ フラップ手術 $24 \sim 26$ EMD (Emdogain ${ }^{\circledR}$ Gel; Biora AB 社), 28 抜歯, $34 \sim 37$ FOP 34,35,36 EMD， 38 抜歯,

4) 再評価 (2000 年 9 月)

5）歯科矯正治療 (2000 年 11 月～ 2002 年 1 月) 22 抜歯，患者の希望により上顎歯列のみ行う。

6) 再評価 $(2002$ 年 1 月)

7) 最終補緅 (2003 年 1 月～4 月) 17, 16, 15, 24, $25,26,35,36,46$ 全部鋳造冠

8）メインテナンス (2003 年 4 月〜)

\section{1. 歯周基本治療}

歯周基本治療として，口腔清掃指導と共に急性炎症 症状の緩和のためにテトラサイクリン系抗菌薬(ミ) マイシン $\left.{ }^{\circledR}\right)$ を 5 日間投与した。全顎のスケーリング, 下顎前歯部の暫間固定，咬合調整を行い，浸潤麻酔下 


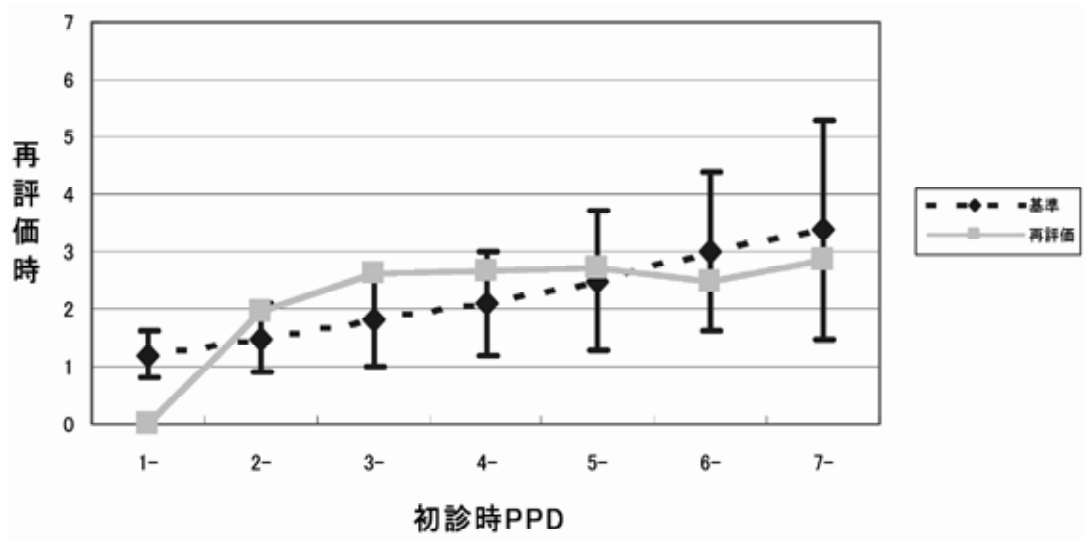

図 6 歯周基本治療による歯周ポケットの改善評価（PD レスポンス表）

初診時

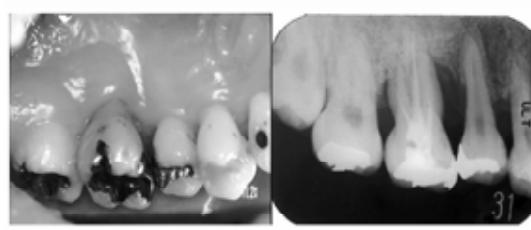

移植 6ヶ月後

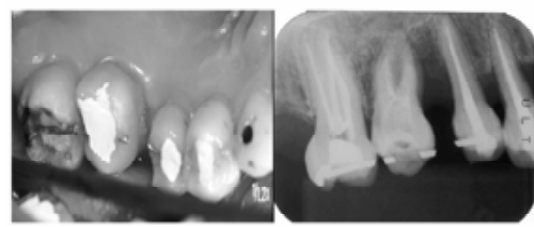

移植時

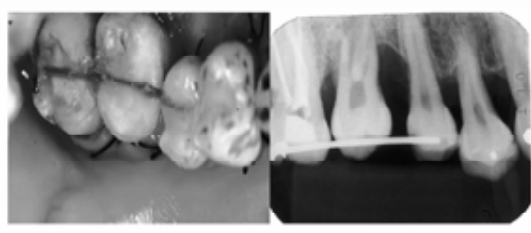

移植 5 年後

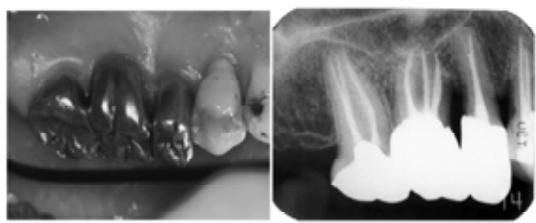

図 7 上顎右側第 1 大臼歯部への上顎右側第 3 大臼歯の歯移植

でのスケーリング・ルートプレーニングをおこなった。 そのとき，下顎前歯部では浮遊歯である 41 を抜歯し その歯をポンテックとして 43 〜 33 を接着性コンポ ジットレジンで固定した。歯周基本治療に反応して歯 肉の炎症所見は見られなくなったが, 歯肉の退縮がみ られそれに伴って強い知覚過敏症状があらわれた。日 常生活やブラッシングに影響が見られたため，臼歯部 で抜髄処置を行った。

そのため，PCR は 30\%台であったがその後 20\% 台 となった。

\section{2. 再評価}

再評価検査の結果, $4 \mathrm{~mm}$ 以上の PPD が $72 \%$ から $16 \%$ に減少し, 平均 PPD \& $6.4 \mathrm{~mm}$ から $2.8 \mathrm{~mm}$ と なった。BOP も $78 \%$ から $32.7 \%$ となり，歯肉の炎症 が消退したがそれに伴い歯肉の退縮が著明となった (図 5)。歯周基本治療の改善度を表す評価 ${ }^{8)}$ の歯周ポ
ケットレスポンスでも良好な反応状態であった。（図 6)

3. 歯周外科治療

1）上顎右側臼歯部

フラップ手術行時に 16 を抜歯し，18 ドナー歯と して水平的に 90 度回転させ 16 の部位へ歯移植を行っ た。経時的に観察し移植後アンキローシスや置換性吸 収も観察されなかったので，6ケ月後に根管充填を行 い, 上顎の矯正治療後に最終補綴処置を行った。移植 歯の近心部では歯槽骨の回復は, 歯根長 $1 / 2$ 程度で あったが，遠心においては歯䅡部付近まで回復されて いた(四 7)。

\section{2）下顎右側臼歯部}

同部フラップ手術を行い，埋伏 48 を抜歯した。 46 の近心に垂直性の骨吸収と舌側にClass I の根分岐部 病変を確認したが，コントロール可能であると判断し 


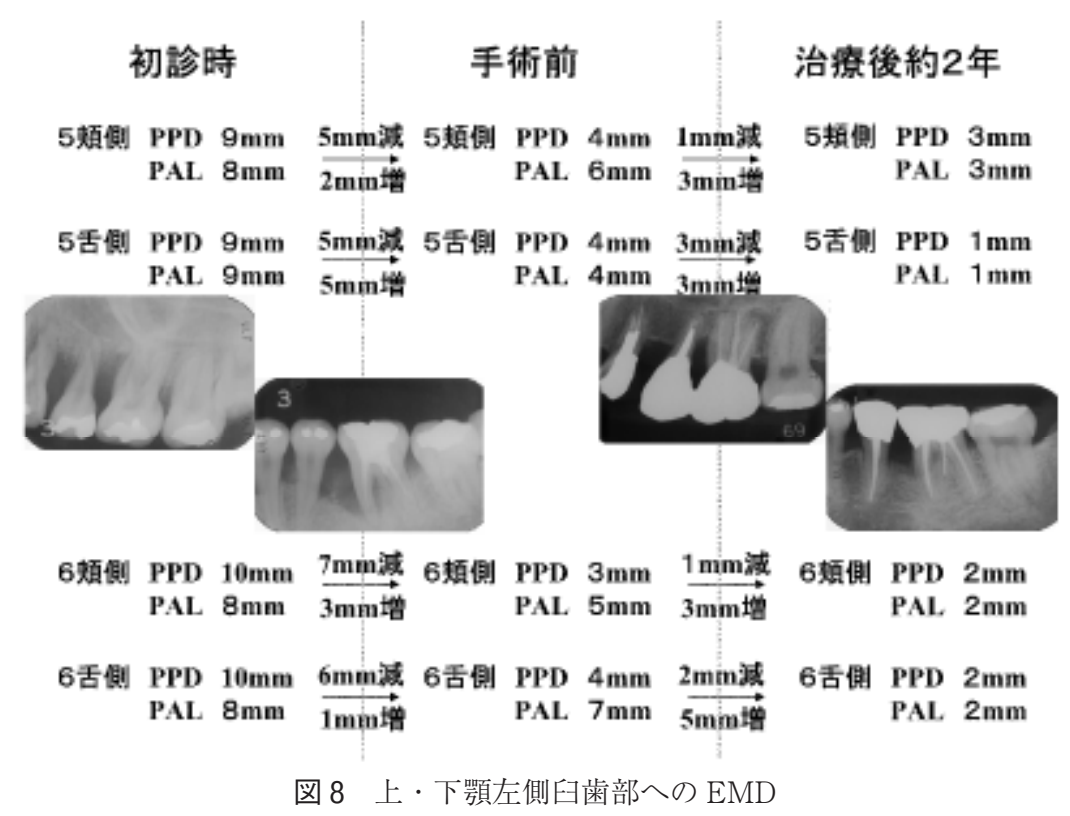

たので，フラップ手術のみとした。

3）上顎左側臼歯部

24 の口蓋側は根尖におよぶ程の骨吸収と 25,26 に 水平·垂直性の混合型の骨吸収がみられたので, フラッ プ手術と同時に EMD 療法を行った。

\section{4）下顎左側臼歯部}

右側と同様に埋伏智歯を抜歯し，36に近心から分岐 部にかけてすり鉢型の骨欠損がみられ，Class II の根 分岐部病変で分割抜去も考えられたが，歯周基本治療 で組織治癒の反応が見られたので, EMD 療法を行う こととした。Emdogain ${ }^{\circledR} \mathrm{Gel}$ は，34,35にも応用した (困 8)。

\section{4. 再評価}

全顎的に PPD は $3 \mathrm{~mm}$ 以下となり, 歯肉の炎症も 消退して上顎前歯部のフレアアウトの改善傾向が見ら れた。上・下顎前歯部は歯周基本治療に良く反応し, $\mathrm{PPD}$ の低下と同時に歯肉退縮をみとめた。上顎は審 美的要因を重視し歯周外科は行わなかった，また下顎 は支持組織が極めて少ないため, 非外科的な処置とし た。しかし患者は, 前歯部の歯肉退縮と歯列不正の改 善を希望したので歯列矯正を行うことにした。ただし 患者は上顎のみの矯正治療を希望した。

\section{5. 矯正治療}

舌癖がみられたので, 舌訓練(筋機能療法)の指導も 並行して行った。舌側転位していた上顎左側側切歯を 抜歯し，前歯部を圧下しながらスペースを閉鎖した。

\section{6. 最終補緅処置}

矯正治療終了後保定処置も含めて最終補綴処置に移 行した。支持力不足を考慮して $17,16,15$ および 25,26 は連結冠を作成し，24 は硬質レジン前装冠を $35,36,46$ は全部鋳造冠とした。

\section{7. メインテナンス}

メインテナンス移行後 6 ケ月の口腔内写真および $\mathrm{X}$ 線写真(図 $9-1,2$ ), 歯周組織検査を示す(困 10)。 $\mathrm{PPD}$ の平均は初診時 $6.43 \mathrm{~mm}$ から $1.65 \mathrm{~mm}$ となり, 15 煩側遠心に $4 \mathrm{~mm}$ のポケットが見られたが, 他は全 て $3 \mathrm{~mm}$ 以下であった (図 11)。BOP も初診時全顎 $78 \%$ ，歯間部 $86.6 \%$ から全顎 $10.3 \%$ ，歯間部 $15.4 \%$ と 減少し炎症所見が改善された。

メインテナンス 4 年後の PCR-Invader 法による唾 液の細菌検査で総菌数に占める目的菌数の比率は, Actinobacillus actinomycetemcomitans が 0.005\%, Porphyromonas gingivalis が $0.00 \%$, Prevotella intermedia が 0.03\%, Tannerella forsythensis が $0.01 \%$ ，で全て正常範囲内であり細菌学的リスクはコ ントロールされている。

リスクアセスメントにおいて, Lang and Tonetti ${ }^{8)}$ による Periodontal risk assessment にて評価すると BOP $10.3 \%$ 、年齢に対する歯槽骨の衰失率が 2 とな り, Periodontal risk が中程度であった。そのためメイ ンテナンス治療の処方箋を作成 (図 12) し口腔内の管 理を行うと共に，心理的要因やストレスを把握するた めにSTAIをとり不安状態をみた。それによると特性 不安 $44 \mathrm{III}$ (普通), 状態不安 46 IV (高い)であり初診時 

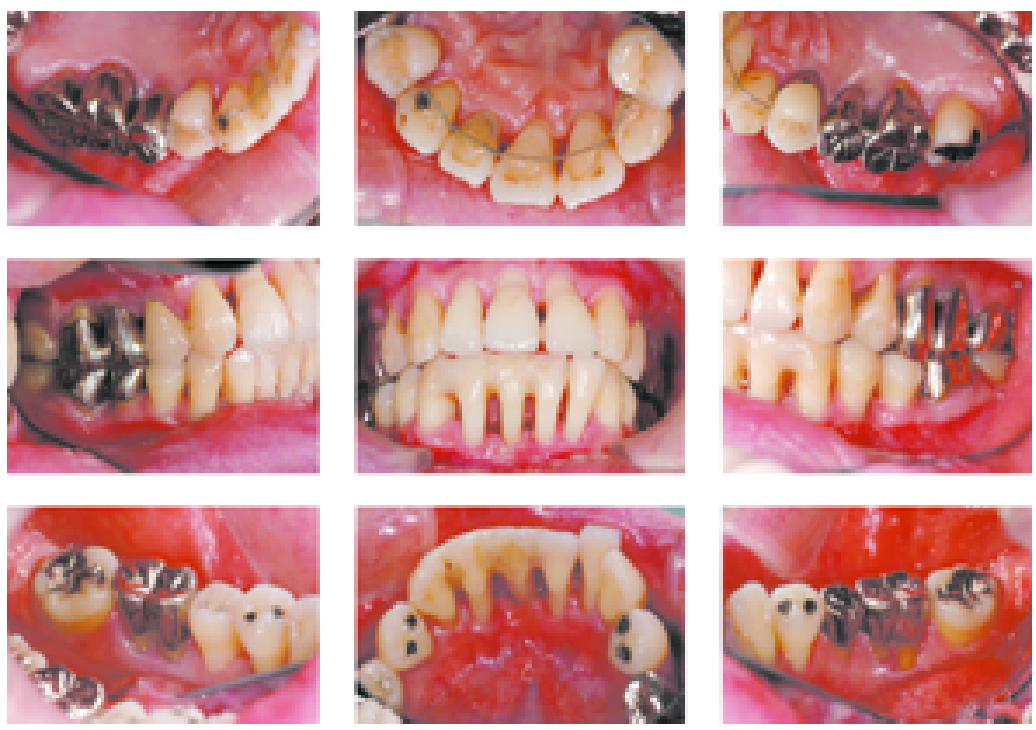

図 9-1 メインテナンス時の口腔内写真

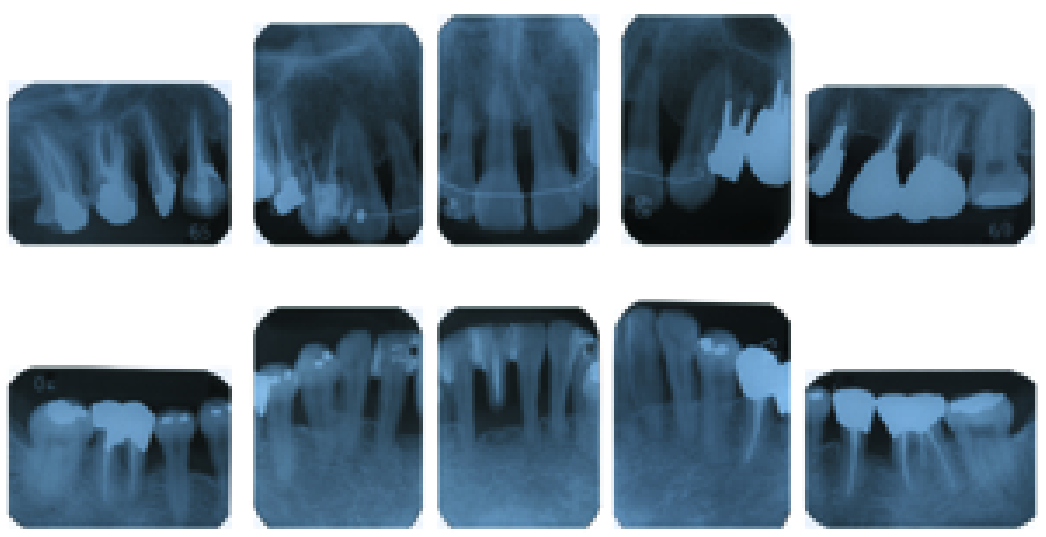

図 9-2 メインテナンス時の X 線写真

に比べて状態不安が上がっていたので，診療に対する 不安や予後に対する不安を話し合うことで解消をおこ なうことで，患者への精神的なサポートを行った。

\section{考察}

本症例は，歯周炎を除き全身的に健康ではあるが， 広汎に急速な歯周組織破壊，家族内発現を認めること により, 広沉型侵襲性歯周炎と診断されたものである。 侵襲性歯周炎の細菌学的特徵としては, A. actinomycetemcomitans が考えられているが，集団によっては P.gingivalis が多く見られると言われている。特に日 本においてはP.gingivalis が多い傾向が強いと報告さ れている9)。しかしながら, Picolos ら ${ }^{10)}$ の報告による と慢性歯周炎(限局型, 広汎型), 侵襲性歯周炎(限局型,
広沉型)での細菌学的, 免疫学的な違いは見出せなかっ たといわれている。本症例においても, 細菌学的特徵 は見られなかった。侵襲性歯周炎の細菌学的特徵は限 定できないのかもしれない。その意味でも抗菌療法 は, 症例ごとの細菌検査を行った後に考慮すべきもの かもしれない。

広沉型侵襲性歯周炎では, 広範囲の支持組織の減少, 歯の動摇や病的移動が見られ歯周組織の持続的な破壊 が進行している。この様な症例においては, 歯周組織 の炎症の除去および咬合の再構築を考え矯正治療を含 めた包括的治療が必要である11)。この様な治療をす すめるためには，患者のコンプライアンスを高め，患 者とのラポールを得なければならない。そのため, 我々は患者の心理的要因を知るために不安尺度を調べ るSTAIを取っている。それによると, 紹介患者と非 


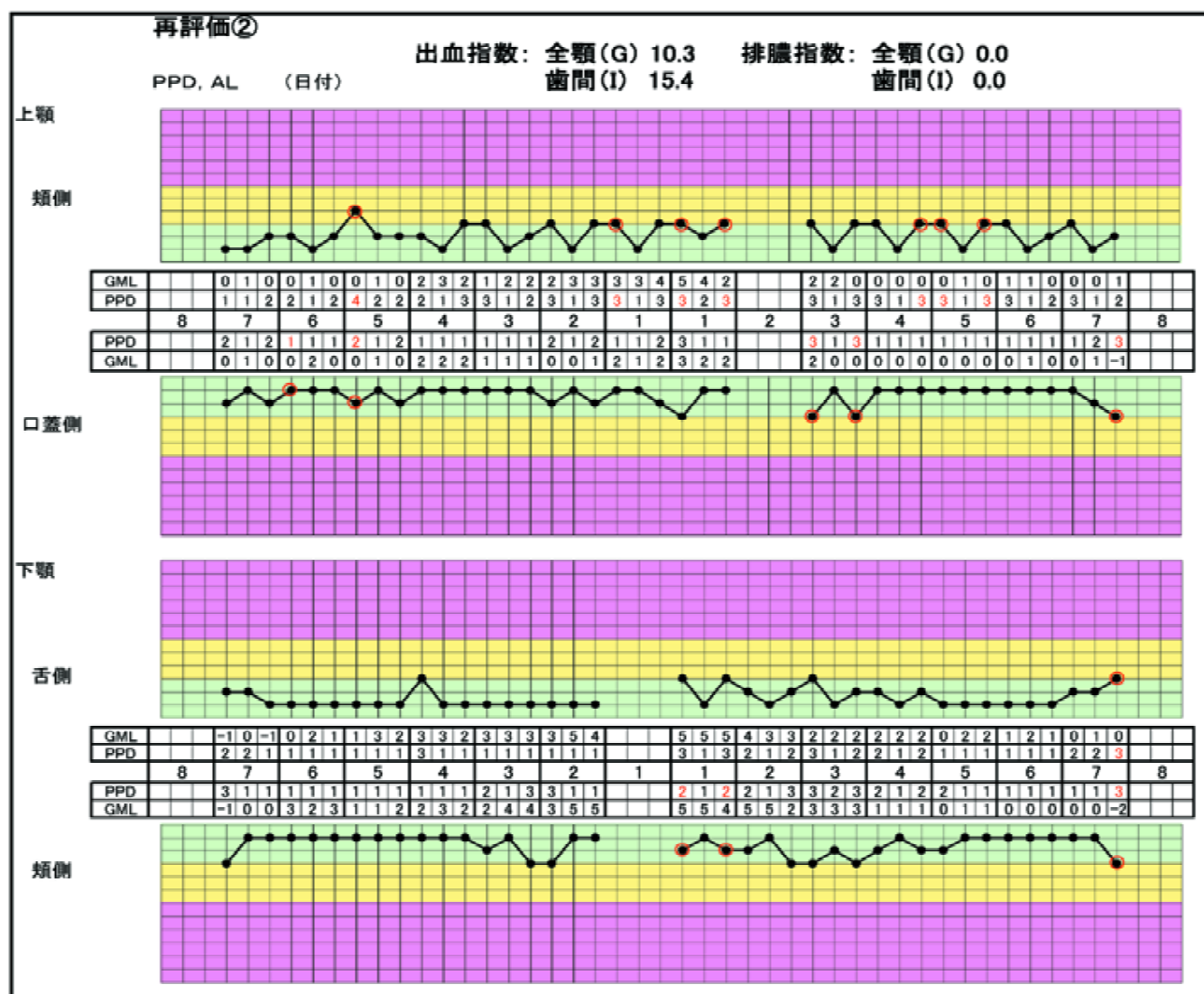

付着菌肉
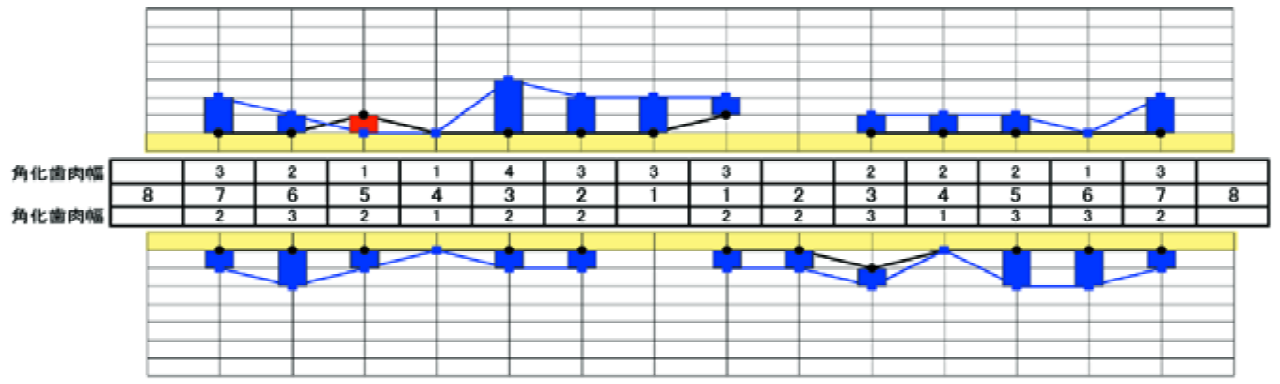

接触点

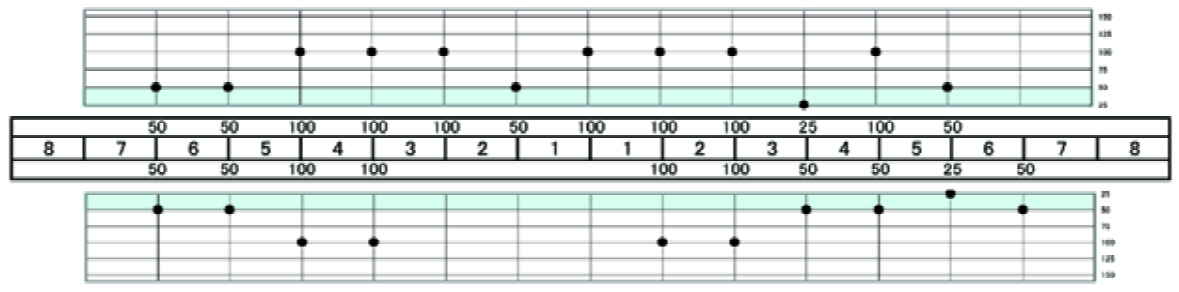

動摇度

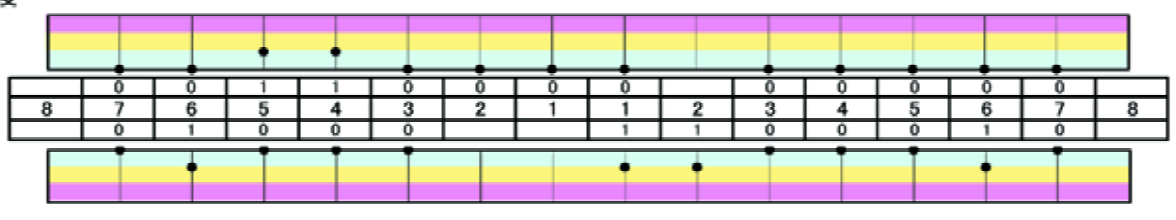

図 10 メインテナンス時の歯周組織検査 


\section{PPDの変化}

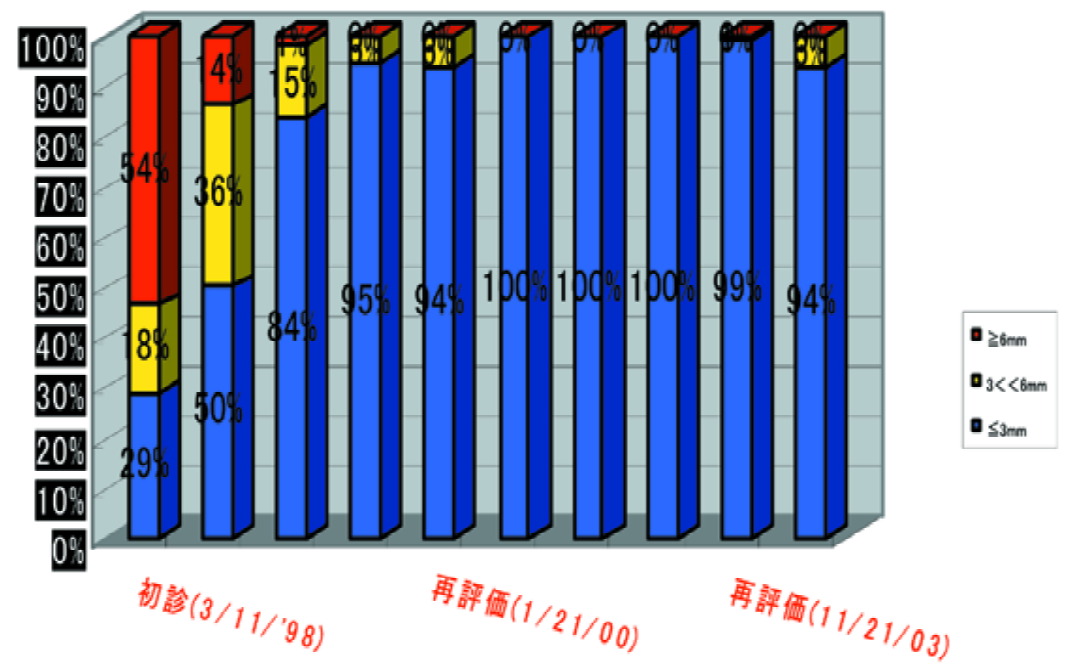

図 11 歯周ポケットの変化

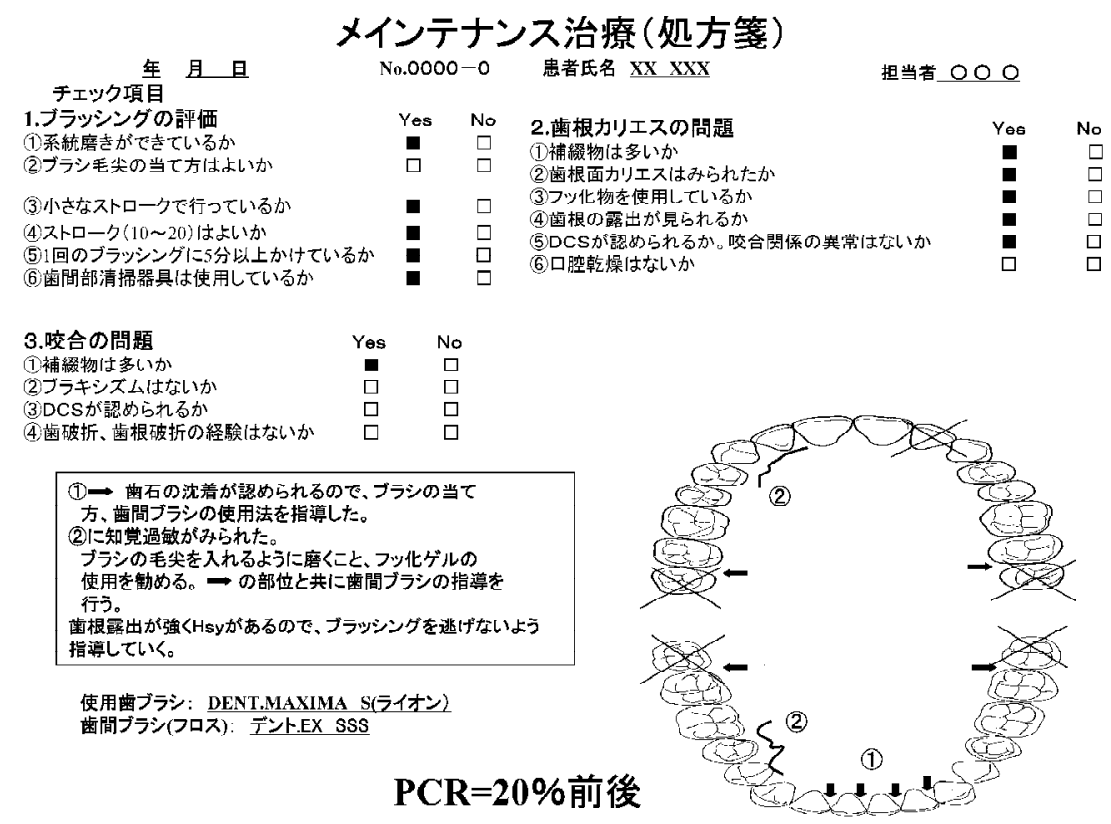

図 12 メインテナンス治療の処方箋

紹介患者では前者において不安傾向が高いことや，歯 周疾患の重症度との関連性はみられなかった ${ }^{7)}$ 。その 様なことを踏まえコミュニケーションを取りながら治 療をすすめると同時に, メインテナンス期においても STAI を使用している。

前歯部の治療に扔いて，歯周基本治療によく反応し 歯肉の炎症, PPD の減少を認めたが, 強い歯肉の退縮 がみられたため歯周外科は行わず，審美的回復を含め
下顎前歯部の固定と上顎の矯正治療を行った。曰歯部 の治療において, 16 は破壊が強く根分岐部病変が見ら れ保存不可能であった。小臼歯部の支持力に問題があ るので，18をドナー歯とする歯移植を行った。16の 骨吸収が強く抜歯窩への保持を得やすくするためド ナー歯を水平的に 90 度回転させ移植した。ドナー歯 の歯根膜による骨誘導を期待したが, 遠心部では十分 回復したが近心部では歯根長 $1 / 2$ 程度であった。広沉 
型侵襲性歯周炎においても歯移植の可能性を示唆した が，骨欠損幅によって骨再生に限界があることが示さ れた。ただ, PPD も $3 \mathrm{~mm}$ 以下で根分岐部病変も見ら れなかった。

上・下顎左側臼歯部に EMD による歯周再生療法を 行った。上顎においては 1 壁性から 2 壁性骨欠損で, 下顎では 1 壁性および 2 度の根分岐部病変であった が, 付着の獲得は 3〜 $5 \mathrm{~mm}$ で X 線所見で骨の増加が みられた。EMDによる治療で, 対照群が設定された 前向き臨床研究での効果については, 付着の獲得は $2.2 \sim 3.4 \mathrm{~mm}$ で骨の再生もみられており ${ }^{12-14)}$, 本症 例と同程度であった。歯周組織再生療法の臨床応用の 適応に関して，(1)EMDのみは，深く・良い外壁があ る久損の場合, (2) EMD と移植材の併用は, 中程度か ら深く，あまり外壁がない骨内欠損の場合，(3) EMD と移植材を併用でバリアー膜使用は, 浅い骨内欠損を 伴う歯槽骨頂の欠損の場合とされ，いずれもフラップ をより歯冠側に設定できる場合とされている，また根 分岐部病変では効果は低いといわれている15)。本症 例の場合は，併用療法の方がより効果的であったかも しれないが, 歯周基本治療で歯肉の退縮がみられたの で, EMDのみで行ったが, 良好な結果が得られた。

メインテナンスにおいて, 後戻りしにくい口腔内環 境整備が必要である。長期メインテナンス患者を診て いると，根破折や根面カリエスを起こす例が多くなる ことを観察している。そのため, フッ化物の使用や咬 合のチェックを行っており, 本症例においても行った。 侵襲型歯周炎の包括的治療によって疾患を $95 \%$ 阻止 できるが，2～5\%は再発を起こす可能性があるとい われている6)。今後メインテナンスの維持が非常に重 要であるが, モチベーションの低下を起こさないよう にするためには, 繰り返しのプラークコントロールの 指導と共にSTAI や細菌検査の使用も有効と考える。

本論文の要旨は, 第 49 回秋季歯周病学会学術大会 (2006 年 9 月 21 日) において発表した。

\section{文献}

1) Schluger, RC. : 青野正男(監訳)：シュルーガー最 新歯周治療学. 医歯薬出版, 1981, 55-71.

2) Page, RC. and Schroeder, HE : Periodontitis in Man and Animals. A comparative review, Basel, Kargar, 1982.

3) Nevins, M. Becker, W. Kornman, K : 池田克己,
石川 烈, 岡田 宏, 長谷川鉱司 (訳) : AAP 歯周疾 患の最新分類. クインテッセンス出版, 東京, 1992.

4）アメリカ歯周病学会編：石川 烈(監訳)：AAP 歯 周疾患の最新分類. クインテッセンス出版, 東京, 2001，9-14

5）島内英俊, 高柴正悟, 西原達次, 川瀬俊夫, 高田 隆, 原 宜興, 山崎和久, 山本松男: 日本歯周病学 会による歯周病分類システム。日歯周誌, 49:3-12, 2007.

6) Buchmann R, Nunn ME, Van Dyke TE, Lange DE : Aggressive periodontitis : 5-year follow-up of treatment. J Periodontol, 73 : 675-683, 2002.

7) 中村太志, 内藤 徹, 村岡宏祐, 横田 誠: 大学病 院に紹介された歯周疾患患者にみられた性格特性の 偏りに関する研究. 日歯心身, $16: 55-58,2001$.

8) Lang NP, Tonetti MS : Periodontal risk assessment (PRA) for patients in supportive periodontal ; therapy (SPT). Oral Health Prev Dent. 1:7-16, 2003.

9) Ishikawa I, Kawashima $Y$, Oda S, Iwata $T$, Arakawa $\mathrm{S}$ : Three case reports of juvenile aggressive periodontitis associated with porphyromonas gingivalis in younger patients. J Periodont Res. 37 : 324-332, 2002.

10) Picolos DK, Lerche-Sehm J, Abron A, Fine JB, Papapanou PN : Infection patterns in chronic and aggressive periodontitis. J Clin Periodontol. 32 : 1055-1061, 2005.

11) Linde J : Textbook of clinical Periodontology, 2nd ed, Munksgaard, Copenhagen, 1989, 563-589.

12) Heijl L, Heden G, Svärdstöm G, Östgren A : Enamel matrix derivative (EMUDOGAIN ${ }^{\circledR}$ ) in the treatment of intrabony periodontal defects. J Clin Periodontol. 24 : 705-714, 1997.

13) Pontoriero R, Wennström J, Lindhe $J$ : The use of barrier membranes and enamel matrix proteins in the treatment of angular bone defecta. A prospective controlled clinical study. J Clin Periodontol. 26 : 833-840, 1999.

14) Sculean A, Windisch P, Chiantella GC, Donos N, Brecx MI, Reich E : Treatment of intrabony defects with enamel matrix proteins and guided tissue regeneration. A prospective controlled clinical study. J Clin Periodontol. 28 : 397-403, 2001.

15) Stuart F, Jeffrey L, Robert H, Rruce D : The use of enamel matrix derivative in the treatment of periodontal osseous defects. A clinical decision tree based on biologic principles of regeneration. Int J Periodontics Restorative Dent. 21 : 437-449,2001. 